\title{
A note on the effect of lamb growth potential, litter size, and concentrate supplements on performance of lambs and lactating ewes consuming low to moderate quality grass hay ${ }^{*}$
}

\author{
A. L. Goetsch \\ Dale Bumpers Small Farms Research Center, USDA, ARS \\ 6883 South State Highway 23, Booneville, Arkansas 72927-9214, USA
}

(Received 6 June 1997; accepted 14 January 1998)

\begin{abstract}
Thirty-eight multiparous St. Croix ewes bred to Romanov or Suffolk rams were used in an 8week experiment beginning $2.9 \pm 0.15$ days after parturition to determine effects of sire breed (i.e., lamb growth potential), litter size (i.e., single vs twins), and different supplemental concentrate treatments on ewe and lamb performance. Wheat hay ( $10 \%$ crude protein and $71 \%$ NDF; DM basis) consumed ad libitum by ewes and lambs was supplemented for ewes (DM basis) with: $0.25 \%$ body weight (BW) of ground maize (control); $1.25 \% \mathrm{BW}$ of maize, $0.3 \% \mathrm{BW}$ of a mixture of fish $(38.8 \%)$, blood $(30.6 \%)$, and feather meals $(30.6 \%$; MR); or $1.25 \%$ BW of maize alone in weeks 1 to 3 and with high-protein feedstuffs in weeks 4 to 8 (M-MR). Control ewe BW decreased during the experiment at a rate of $67 \mathrm{~g} /$ day, whereas BW change for MR and M-MR treatments was 16 and $-8 \mathrm{~g}$ /day, respectively (control vs $\mathrm{MR}$ and $\mathrm{M}-\mathrm{MR}, \mathrm{P}<0.05 ; \mathrm{SE} 7.8$ ). Lamb BW gain also was lower for control than for MR $(\mathrm{P}<0.05)$ and M-MR $(\mathrm{P}=0.08), 144,205$, and $190 \mathrm{~g} /$ day for control, MR, and M-MR, respectively (SE 12.9). Lamb BW gain was greater $(\mathrm{P}<0.05)$ for Romanov- vs Suffolk-sired lambs (196 vs $163 \mathrm{~g}$ /day; SE 8.7) and for single than for twin lambs (198 vs $162 \mathrm{~g}$ /day; SE 9.0).
\end{abstract}

KEY WORDS: sheep, liveweight gain, breed, supplementation, lactation

\footnotetext{
* Mention of a trademark or proprietary product in this paper does not constitue a guarantee or warranty of the product by the USDA or the ARS and does not imply its approval to the exclusion of other products that may be suitable
} 


\section{INTRODUCTION}

Milk production by ewes typically peaks in the second and third weeks of lactation, whereas, feed intake is greatest in weeks 5 and 6 (Rattray, 1992). Hence, concentrates are often used to supplement ewes consuming low to moderate quality forage-based diets to satisfy energy and amino acid demands of lactation, which are greater for multiple vs single lambs. However, it is unclear if growth potential of lambs, as influenced by sire breed, has effects on nutrient demands for lactation similar to those of litter size.

Often the composition of concentrate supplements for ewes is constant throughout lactation, although the quantity may vary as lactation advances and milk production slowly declines after the peak, with increasing dry feed consumption by lambs as lactation advances, and(or) with changes in forage quality or availability. Partitioning of dietary nutrients to the mammary gland and peripheral tissue mobilization in early lactation involve numerous physiological processes (e.g., hormone levels and activity of receptors), many of which are affected by levels and changes in nutrient absorption. Hence, temporal shifts in the level and composition of supplemental concentrate in early lactation could elicit physiological changes that alter the magnitude or length of peak milk production and, hence, improve lamb growth. Therefore, objectives of this experiment were to investigate effects of biological type or growth potential of lambs, lamb gender, litter size, and different concentrate supplements on performance of ewes and lambs in the first 8 weeks of lactation while consuming low to moderate quality grass hay.

\section{MATERIAL AND METHODS}

Thirty-eight multiparous St. Croix ewes were used in a completely randomized design experiment, which began in late-winter, early-spring of 1997. Ewes were from a larger group bred to Romanov or Suffolk rams in the fall of 1996. Because the number of open ewes differed between sire groups, there were 24 ewes with Suffolk x St. Croix lambs and 14 with Romanov x St. Croix. Also, 16 ewes had single lambs and 22 reared twins, for a total of 60 .

The experiment was 8 weeks long and began a few days after birth $(2.9 \pm 0.15$ days). Lambs were weighed, castrated, and docked by banding at birth. Ewes lambing on Monday to Wednesday began the experiment on Friday, and ones lambing on Thursday through Sunday started on Tuesday. Ewes were weighed and condition scored ( 1 = very thin; $5=$ very fat) upon initiation of the experiment and then were placed in one of eight partially covered $3 \times 12.2 \mathrm{~m}$ concrete pens (two per supplement treatment). Placement was in accordance with a random allotment order within lamb breed group and litter size. 
Square bales of wheat hay (Triticum aestivum; early head emergence) were available free-choice in each pen, and a 3-m long supplement feeder was present. Supplement treatments were (DM basis): $0.25 \%$ body weight (BW) of ground maize for 8 weeks (control treatment); $1.25 \% \mathrm{BW}$ of maize plus $0.3 \% \mathrm{BW}$ of a mixture of feedstuffs high in ruminally undegradable protein (RUP) for 8 weeks (MR treatment); and $1.25 \%$ BW of maize in weeks 1 to 3 and $1.25 \%$ BW of maize plus $0.3 \%$ BW of RUP in weeks 4 to 8 (M-MR treatment). The RUP mixture consisted of (\%): fish 38.8 , blood 30.6, and feather 30.6, meals. Supplement amounts were based on initial BW. Supplements were given at $8.00 \mathrm{~h}$ daily, after being thoroughly mixed with a mineral-vitamin premix ( $20 \mathrm{~g} /$ day; contained at least, $\%$ : $\mathrm{Ca} 12.5, \mathrm{P}$ 12, $\mathrm{NaCl} 18, \mathrm{Zn} 0.8, \mathrm{Fe} 0.7, \mathrm{Mn} \mathrm{0.5,} \mathrm{O} 0.02$, Co 0.005, and $\mathrm{Se} 0.00015$, and 2.2 million IU vitamin A, 0.45 million IU vitamin $\mathrm{D}_{3}$, and $275 \mathrm{IU}$ vitamin $\mathrm{E} / \mathrm{kg}$; air-dry basis). Lambs had free access to wheat hay; however, supplement feeders were elevated to minimize supplement consumption by lambs. At the time of change in supplement composition for the M-MR treatment, ewes and lambs were moved to similar pens until all ewes in a group received the same supplement. Ewe body weight (BW) and condition score and lamb BW were determined after 3 and 8 weeks.

Feedstuffs were sampled weekly. Hay was ground to pass a 1-mm screen and analyzed for dry matter (DM), ash, Kjeldahl nitrogen (AOAC, 1984), NDF, ADF, and ADL (filter bag technique; ANKOM Technology Corp., Fairport, NY). Cellulose was determined as loss in weight upon sulphuric acid treatment and hemicellulose as the difference between neutral and acid detergent fibre concentrations. Concentrates were analyzed for DM and N.

Data were analyzed by General Linear Models procedures of SAS (1990), with ewe data as a split-split plot and lamb data as a split-split-split plot. The full model for lamb data consisted of treatment, pen within treatment (error term for treatment), breed, litter size, gender, and interactions among treatment, breed, litter size, and gender. Initial values were included as covariates for performance variables. The full model for ewe data was the same except for omission of terms with lamb gender. Reduced models with omission of interactions because of P-values greater than 0.10 were used. Differences among means were determined by least significance difference procedures with a protected F-test $(\mathrm{P} \leq 0.07)$.

\section{RESULTS}

Wheat hay was slightly lower in crude protein (CP) and higher in neutral detergent fibre than expected (Table 1). Initial ewe BW and condition score were $44.0 \mathrm{~kg}$ (SE 1.37) and 2.3 (SE 0.11), respectively. Lamb birth weight averaged $4.4 \pm 0.28$, $3.9 \pm 0.12,3.8 \pm 0.15$, and $4.1 \pm 0.17 \mathrm{~kg}$ for single, twin, Romanov-sired, and Suffolk-sired lambs, respectively. 
control (1.64, 3.02, and 2.89 for control, MR, and M-MR, respectively; SE 0.096). Average CP intake was 76, 242, and $174 \mathrm{~g}$ /day (SE 8.4), and CP was 10.0, 17.6, and $14.97 \%$ of DM intake (SE 0.18 ) over the entire experiment. Digestible energy (DE) intake averaged 8.0,17.2, and $14.6 \mathrm{MJ} /$ day (SE 0.77), and DE concentration in dietary DM averaged 10.5, 12.6, and $12.6 \mathrm{MJ} / \mathrm{kg}$ (SE 0.08 ) over the entire experiment.

Ewe BW change was lower $(\mathrm{P}<0.05)$ for control than for MR; whereas, in weeks 4 to 8 ewe BW change was similar among treatments $(\mathrm{P}>0.10$; Table 2$)$. For the entire experiment, however, ewe BW change was lowest $(\mathrm{P}<0.05)$ among treatments for control. Change in ewe condition score was similar among treatments in weeks 1 to 3 and 4 to 8 ; however, change was lower $(\mathrm{P}<0.05)$ for control vs MR and M-MR.

Lamb BW gain in weeks 1 to 3 did not differ among treatments (Table 3). In weeks 4 to 8 and 1 to 8 , lamb BW gain was lowest $(\mathrm{P}<0.05)$ for control vs MR $(\mathrm{P}=0.06$ and $<0.05$, respectively $)$ and $\mathrm{M}-\mathrm{MR}(\mathrm{P}<0.05$ and $=0.08$, respectively).

TABLE 3

Effects of sire breed, litter size, and different concentrate supplement treatments on change in lamb

\begin{tabular}{|c|c|c|c|c|}
\hline \multirow[b]{2}{*}{ Item } & \multicolumn{4}{|c|}{ Week of lactation' } \\
\hline & number & 1 to 3 & 4 to 8 & 1 to 8 \\
\hline & & & & \\
\hline \multicolumn{5}{|l|}{ Supplement treatment ${ }^{2}$} \\
\hline control & 20 & 170 & $126^{\mathrm{a}}$ & $144^{\mathrm{a}}$ \\
\hline MR & 21 & 237 & $183^{\mathrm{ab}}$ & $205^{b}$ \\
\hline M-MR & 19 & 188 & $199^{\mathrm{b}}$ & $190^{\mathrm{ab}}$ \\
\hline SE & & 22.0 & 14.5 & 12.9 \\
\hline \multicolumn{5}{|l|}{ Sire breed ${ }^{3}$} \\
\hline Romanov & 24 & 207 & $188^{\mathrm{b}}$ & $196^{\mathrm{b}}$ \\
\hline Suffolk & 36 & 182 & $150^{\mathrm{a}}$ & $163^{\mathrm{a}}$ \\
\hline SE & & 12.5 & 11.2 & 8.7 \\
\hline \multicolumn{5}{|l|}{ Number of lambs ${ }^{4}$} \\
\hline 1 & 16 & 211 & $189^{\mathrm{b}}$ & $198^{\mathrm{b}}$ \\
\hline 2 & 44 & 179 & $150^{\mathrm{a}}$ & $162^{a}$ \\
\hline SE & 12.4 & 11.6 & 9.0 & \\
\hline
\end{tabular}

1 started on the experiment at 2 to 5 days after parturition

${ }^{2}$ control $=0.25 \%$ body weight $(\mathrm{BW})$ of ground maize; $\mathrm{MR}=1.25 \% \mathrm{BW}$ of maize plus $0.3 \% \mathrm{BW}$ of feedstuffs high in ruminally undegradable protein (RUP); and M-MR $=1.25 \% \mathrm{BW}$ maize in weeks 1 to 3 of lactation and $1.25 \%$ BW of maize plus $0.3 \%$ BW of RUP in weeks 4 to 8

${ }^{3}$ birth weight: $3.8 \pm 0.15$ and $4.1 \pm 0.17 \mathrm{~kg}$ for Romanov- and Suffolk-sired lambs, respectively

${ }^{4}$ birth weight: $4.4 \pm 0.28$ and $3.9 \pm 0.12 \mathrm{~kg}$ for singles and twins, respectively

$\mathrm{a}, \mathrm{b}-$ means in a row without a common superscript differ at $\mathrm{P}<0.05$ 
Sire breed and number of lambs born numerically affected $(P=0.15$ and 0.09 , respectively) lamb BW gain 1 to 3 and 4 to 8 , although effects were significant $(\mathrm{P}<0.05)$ in weeks 1 to 8 , with lamb BW gain being greater for lambs from Romanov vs Suffolk rams and for single vs twin lambs. Lamb gender did not affect BW gain.

\section{DISCUSSION}

\section{Dietary treatments}

Lower changes in ewe BW and condition score and in lamb BW for control than for $\mathrm{MR}$ reflect limiting intakes of $\mathrm{CP}$ and $\mathrm{DE}$ for the control treatment. Based on dietary concentrations, digestibility or $\mathrm{DE}$ intake appeared relatively more limiting than CP for control performance (NRC, 1985). Findings for M-MR do not suggest that the presumed marked increase in amino acid absorption after 3 weeks greatly enhanced milk production as compared with the MR treatment. In accordance, Robinson et al. (1979) suggested that increased milk production in early lactation due to RUP supplementation impacts production in subsequent periods of lactation; depressions in milk production by omitting RUP from lactating ewe diets, commencing at 10 days of lactation, for more than 10 days extended beyond the period of feeding the low protein diet. However, in the present experiment lamb BW gain was similar in weeks 1 to 3 and 4 to 8 for M-MR in contrast to greater gain in the first 3 weeks vs the subsequent 5 for MR. Perhaps the presumably lower level of milk intake by lambs in weeks 1 to 3 for M-MR than for MR hastened the transition to solid feed and increased hay intake. Alternatively, the effect on M-MR lamb BW gain of any increase in milk production from 4 to 8 weeks due to RUP supplementation could have been accentuated by capacity for compensatory growth. Another factor that may have prevented significant differences in lamb growth rate between MR and M-MR treatments is ewe body energy status (Robinson et al., 1979); the low to moderate stores of body fat should have minimized potential impact of RUP on milk production by MR ewes in the first 3 weeks of lactation.

\section{Sire breed and number of lambs}

Lower lamb BW gain for Suffolk- vs Romanov-sired lambs and for twin than for single lambs reflects that lactation diets low or marginal in protein and(or) energy can more severely limit growth of lambs of biological types possessing high vs low potential growth rate (i.e., Suffolk- $v s$ Romanov-sired) and of multiple- $v s$ singlebirth lambs. However, factors that could partially compensate with other production conditions include lamb consumption of concentrate or higher quality forage than used in the present experiment. 
Breeds or biological types of ruminants with high milk or growth potential have greater maintenance energy requirements than those with lower potential, and such high production potential may be expressed only with nonstressful nutritional conditions or high quality diets (Ferrell and Jenkins, 1987; Frisch and Vercoe, 1991). Thus, less energy may have been available for tissue accretion by Suffolk-vs Romanov-sired lambs because of less than ad libitum milk intake. A portion of this difference could be attributable to greater birth weight for Suffolk- $v s$ Romanovsired lambs $(0.32 \mathrm{~kg} ; 8.4 \%)$. Conversely, lower BW gain for twin than for single lambs was most likely primarily because of lower milk ingestion per lamb for twins, resulting from relatively low $\mathrm{DE}$ intake and low to moderate body fat reserves for ewes. The absence of interaction between litter size and sire breed reflects that neither factor appreciably altered ewe milk production, presumably because of limited DE intake and low to moderate body fat reserves.

\section{CONCLUSIONS}

Overall, these results do not indicate potential to enhance efficiency of lamb growth during lactation by delaying RUP supplementation until week 4 of lactation. With moderate to low quality basal dietary forage, low to moderate body fat reserves of ewes, and with concentrate consumption by ewes alone, BW gain of lambs with high growth potential may be less than that for lambs with lower growth potential. Effects of such differences in biological type or lamb growth potential and litter size on lamb BW may be additive despite apparent dissimilar causal factors.

\section{ACKNOWLEDGEMENTS}

Appreciation is expressed to S. Haller and J. Cherry for assistance in feeding, animal care, and laboratory analyses.

\section{REFERENCES}

AOAC, 1984. Official Methods of Analysis. 14th Edition. Association of Official Analytical Chemists, Washington, DC

Ferrell, C. L., Jenkins, T. G., 1987. Influence of biological types on energy requirements. In: Proceedings of Grazing Livestock Nutrition Conference, University of Wyoming, Laramie, WY, pp. 1-8

Frisch, J. E., Vercoe, J. E., 1991. Factors affecting the utilization of nutrients by grazing beef cattle in northern Australia. In: Proceedings of 2nd Grazing Livestock Nutrition Conference, Oklahoma Agriculture Experimental Station. MP-133, pp. 198-212 
NRC, 1985. Nutrient Requirements of Sheep. 6th Edition. National Academy Press, Washington, DC

Rattray P. V., 1992. Nutrition of the ewe during gestation and lactation. In: A.W. Speedy (Editor). Progress in sheep and goat research. C.A.B. International. Oxon, UK, pp. 85-106

Robinson J. J., McHattie I., Calderon Cortes J. F., Thompson J. L., 1979. Further studies on the response of lactating ewes to dietary protein. Anim. Prod. 29, 257-269

SAS, 1990. SAS/STAT User's Guide (Version 6, 4th Edition, Volume 2). SAS Institute Inc. Cary, $\mathrm{NC}$

\section{STRESZCZENIE}

Wplyw potencjału wzrostu, liczebności miotu i dodatku paszy treściwej do dawki na rozwój jagniąt i wyniki produkcyjne laktujących owiec, żywionych niskiej lub średniej jakości sianem ląkowym

Ośmiotygodniowe doświadczenie przeprowadzono na trzydziestu ośmiu wielorodnych maciorkach rasy St. Croix, kojarzonych z trykami rasy romanowskiej lub suffolk, rozpoczynając w $2,9 \pm 0,15$ dniu po wykocie. Określano wpływ rasy tryka (t.j. potencjału wzrostowego jagniąt), liczebności miotu (pojedynki lub bliźnięta) i różnych dodatktów paszy treściwej na rozwój jagniąt i wyniki produkcyjne maciorek. Do siana z pszenicy ( $10 \%$ białka ogólnego i $71 \%$ NDF w s.m.), pobieranego do woli przez maciorki i jagnięta, dodawano dla maciorek ( $w \%$ masy ciała) śrutowane ziarno kukurydzy w ilości $0,25 \%$ - grupa kontrolna; $1,25 \%$ kukurydza $+0,3 \%$ mieszanka złożona z ( $\%$ ) mączki rybnej $(38,8)$, krwi $(30,6)$ i pierza $(30,6)$; MR; lub $1,25 \%$ - sama kukurydza od 1 do 3 tygodnia i wysokobiałkowa mieszanka od 4 do 8 tygodnia (M-MR). Masa ciała maciorek kontrolnych zmniejszała się w ciągu doświadczenia o $67 \mathrm{~g} / \mathrm{dzień}$, podczas gdy zmiany m.c. w grupach MR i M-MR wynosiły odpowiednio + 16 i -8 g/dzień (grupa kontrolna vs. MR i M-MR, $\mathrm{P}<0,05 ; \mathrm{SE} 7,8$ ). Przyrosty jagniąt grupy kontrolnej były także mniejsze niż grupy $\mathrm{MR}(\mathrm{P}<0,05)$ i $\mathrm{M}-\mathrm{MR}(\mathrm{P}=0,84)$ i wynosiły odpowiednio 144, 205 i $190 \mathrm{~g}$ /dzień (SE 12,9). Przyrosty jagniąt pochodzących po ojcach romanowskich były większe $(\mathrm{P}<0,05)$ niż. po suffolk $(196 \mathrm{vs} .163 \mathrm{~g} / \mathrm{dzien} ;$ SE 8,7$)$ i większe u jagniąt z urodzeń pojedynczych niż bliźniaczych (198 vs. 162/dzień; SE 9,0). 